\title{
Bioactive Levan-Type Exopolysaccharide Produced by Pantoea agglomerans ZMR7: Characterization and Optimization for Enhanced Production
}

\author{
Safaa A. S. Al-Qaysi ${ }^{1{ }^{*}}$, Halah Al-Haideri', Sana M. Al-Shimmary', Jasim M. Abdulhameed ${ }^{2}$, \\ Othman I. Alajrawy ${ }^{3}$, Mohammad M. Al-Halbosiy ${ }^{4}$, Tarek A. A. Moussa ${ }^{5 *}$, and Mohamed G. Farahat ${ }^{5,6}$ \\ ${ }^{1}$ Department of Biology, College of Science (for Women), University of Baghdad, Baghdad, Iraq \\ ${ }^{2}$ Anbar Education Directors, Al-Anbar, Iraq \\ ${ }^{3}$ Department of Applied Chemistry, College of Applied Science, University of Fallujah, Iraq \\ ${ }^{4}$ Biotechnology Research Center, University of Al-Nahrain, Baghdad, Iraq \\ ${ }^{5}$ Department of Botany and Microbiology, Faculty of Science, Cairo University, Giza 12613, Egypt \\ ${ }^{6}$ Bionanotechnology Program, Faculty of Nanotechnology for Postgraduate Studies, Cairo University, Sheikh \\ Zayed Branch Campus, Sheikh Zayed City, Giza 12588, Egypt
}

Levan is an industrially important, functional biopolymer with considerable applications in the food and pharmaceutical fields owing to its safety and biocompatibility. Here, levan-type exopolysaccharide produced by Pantoea agglomerans ZMR7 was purified by cold ethanol precipitation and characterized using TLC, FTIR, ${ }^{1} \mathrm{H}$, and ${ }^{13} \mathrm{C}$ NMR spectroscopy. The maximum production of levan $(28.4 \mathrm{~g} / \mathrm{l})$ was achieved when sucrose and ammonium chloride were used as carbon and nitrogen sources, respectively, at $35^{\circ} \mathrm{C}$ and an initial pH of 8.0. Some biomedical applications of levan like antitumor, antiparasitic, and antioxidant activities were investigated in vitro. The results revealed the ability of levan at different concentrations to decrease the viability of rhabdomyosarcoma and breast cancer cells compared with untreated cancer cells. Levan appeared also to have high antiparasitic activity against the promastigote of Leishmania tropica. Furthermore, levan had strong DPPH radical scavenging (antioxidant) activity. These findings suggest that levan produced by $P$. agglomerans ZMR7 can serve as a natural biopolymer candidate for the pharmaceutical and medical fields.

Keywords: Levan, exopolysaccharide, characterization, antioxidant, antiparasitic, antiproliferation

Received: January 20, 2021 Accepted: March 30, 2021

First published online: April 05, 2021

*Corresponding authors T.A.A. Moussa

Phone/Fax: +201001531738 E-mail: tarekmoussa@yahoo.com S.A.S.A. Al-Qaysi Phone/Fax: +9647809749633 E-mail: Safaaa_bio@csw. uobaghdad.edu.iq, Safaa.ahmed.bio@gmail.com

pISSN 1017-7825 elSSN 1738-8872

Copyright(C) 2021 by The Korean Society for Microbiology and Biotechnology

\section{Introduction}

Levan is a homo-exopolysaccharide, composed of fructose molecules with a glucose residue linked by $\beta$-(2-6) glycosidic bonds at the end, and this backbone makes levan a unique biopolymer [1]. This biopolymer is produced from sucrose as a sole substrate by many types of microorganisms through the activity of a specific enzyme known as levansucrase (E.C. 2.4.1.10), and released as exopolysaccharides (EPS). Various bacterial genera such as Zymomonas, Pseudomonas, Corynebacterium, Leuconostoc, Bacillus, Lactobacillus, Streptococcus, Gluconoacetobacter, Aerobacter, Brachybacterium, and Enterococcus [2-5], and a few plant species are known to produce levan [6, 7]. Hitherto, more than one hundred bacterial genera were described as levan producers $[2,8]$. Levansucrase is secreted by microorganisms into the extracellular environment particularly at low and neutral $\mathrm{pH}$ [9]. This enzyme works efficiently when sucrose is used as a sole carbon source and displays low activity with other types of sugars such as raffinose, mannose, fructose, glucose, and others [10]. Levan is considered as a water-soluble biopolymer that is also soluble in oil because it contains the $\beta-(2,6)$ linkage. On the other hand, this biopolymer is insoluble in a wide range of organic solvents such as ethanol, methanol, acetone, isopropanol, toluene, etc. Besides being non-toxic and an ocular non-irritant, levan has some additional merits such as fair heat stability, with a melting-point temperature of $225^{\circ} \mathrm{C} \mathrm{[10].} \mathrm{Many} \mathrm{reports} \mathrm{demonstrated} \mathrm{that} \mathrm{levan} \mathrm{is} \mathrm{used} \mathrm{in} \mathrm{the} \mathrm{medicinal} \mathrm{and}$ pharmaceutical industries as an antibacterial, antiviral, antiparasitic, antitumor, antioxidant, antiobesity, hypolipidemic, antidiabetic, immunostimulant and cosmeceutical agent [11-14]. Moreover, this biopolymer can be used in the food industries as a stabilizer, emulsifier, sweetener and thickener as well as in food packaging in levan-based film [15]. Levan is also used in the bread-making industry due to its ability to form a hydrocolloid microgel [16]. Additionally, recent studies suggested that levan can be applied in materials chemistry as it is used 
to strengthen aluminum bars and the binding of some plastics due to its excellent tensile properties $[17,18]$. The broad-spectrum usage and global demand for levan by various industries demonstrate the importance of this biopolymer, which is also known for its versatility, low cost, and large-scale production capability [19]. The present work addresses the ability of Pentoea agglomerans strain ZMR7, isolated from rhizospheric soil of maize plants (Zea mays), to produce a levan-type EPS with promising antitumor, antiparasitic and antioxidant activities.

\section{Materials and Methods}

\section{Isolation, Screening and Identification of EPS-Producing Bacteria}

The rhizospheric soil samples of maize plants (Z. mays) were collected from five farms in Baghdad Governorate, Iraq. Ten grams of rhizosphere soil were suspended in $90 \mathrm{ml}$ of sterilized peptone water (Oxoid, UK) and then the suspensions were serially diluted. Subsequently, $100 \mu \mathrm{l}$ of adequate dilutions were spread on nutrient agar plates (Oxoid, UK) and incubated under aerobic conditions at $35^{\circ} \mathrm{C}$. After incubation for $24-48 \mathrm{~h}$, the growing bacterial colonies were picked up and cultured on modified levan-screening medium ( $1 \%$ tryptone, $0.5 \%$ yeast extract, $0.25 \% \mathrm{~K}_{2} \mathrm{PO}_{4}, 0.5 \% \mathrm{NaCl}, 20 \%$ sucrose and $1.5 \%$ agar) at $35^{\circ} \mathrm{C}$ for $48 \mathrm{~h}$. The slimy mucoid colonies were selected as potential levan producers [20]. The potential levan-producing bacteria were identified by analysis of the 16S rRNA gene sequence amplified using the primer pair, 518F (5'-CCAGCAGCCGCGGTAAT-3') and 1492R (5'GGYTACCTTGTTACGACTT-3') [21].

\section{Production and Isolation of EPS}

Microbial EPS production was performed using production medium [per liter of distilled water (DW): sucrose, 200 g; yeast extract $2.5 \mathrm{~g} ; \mathrm{MgSO}_{4} \cdot 7 \mathrm{H}_{2} \mathrm{O}, 1.0 \mathrm{~g} ; \mathrm{K}_{2} \mathrm{HPO}_{4}, 5.5 \mathrm{~g} ;\left(\mathrm{NH}_{4}\right)_{2} \mathrm{SO}_{4}, 1.0 \mathrm{~g} ; \mathrm{pH}$ 7.2] [22]. Bacterial inocula were prepared in $250-\mathrm{ml}$ Erlenmeyer conical flasks containing $50 \mathrm{ml}$ of nutrient broth. One loopful of overnight bacterial culture was inoculated in nutrient broth and incubated in a shaking incubator $(100 \mathrm{rpm})$ for $48 \mathrm{~h}$ at $35 \pm$ $2^{\circ} \mathrm{C}$. The production media were inoculated with $5 \%(\mathrm{v} / \mathrm{v})$ of the inoculum $\left(7 \times 10^{6} \mathrm{CFU} / \mathrm{ml}\right)$ and incubated at 35 $\pm 2^{\circ} \mathrm{C}$ for $48 \mathrm{~h}$ with gentle agitation $(100 \mathrm{rpm})$. After the incubation period, the culture was centrifuged for $10 \mathrm{~min}$ at $10,000 \mathrm{~g}$ and the cell-free supernatant was mixed with 2 volumes of ice-cold absolute ethanol and chilled at $4^{\circ} \mathrm{C}$ for $48 \mathrm{~h}$. The precipitated EPS was harvested by centrifugation for $15 \mathrm{~min}$ at $15,000 \mathrm{~g}$ at $4^{\circ} \mathrm{C}$ and the pellets were redissolved in DW and deproteinized seven times with 1/5 volume of Sevag reagent (chloroform/n-butanol, 5:1 v/v) [23]. Thereafter, the aqueous layer containing the deproteinized EPS was collected, mixed with 2 volumes of icecold absolute ethanol and chilled at $4^{\circ} \mathrm{C}$ for $48 \mathrm{~h}$. The re-precipitated EPS was collected by centrifugation for $15 \mathrm{~min}$ at $15,000 \mathrm{~g}$ at $4^{\circ} \mathrm{C}$ and the collected pellet was washed three times with 1.5 volumes of absolute cold ethanol. Afterwards, the pellets were dissolved in DW and dialyzed through a membrane with a 10-kDa cutoff against DW several times for three days, freeze-dried and weighed [5]. The EPS content was estimated by the hydrolysis of EPS samples in $0.1 \mathrm{M} \mathrm{HCl}$ for $1 \mathrm{~h}$ at $100^{\circ} \mathrm{C}$ and the content of EPS in the hydrolyzed solution was analyzed as D-fructose by the dinitrosalicylic acid method [24]. The obtained quantity of D-fructose was then divided by a factor of 1.11 to calculate the amount of levan. The strain designated ZMR7, exhibiting maximum levan production, was selected for further investigations $[25,26]$.

\section{Characterization of the EPS}

Thin-layer chromatography (TLC) of the acid-hydrolyzed biopolymer was conducted to investigate the composition of the EPS produced by P. agglomerans ZMR7. Briefly, the EPS was hydrolyzed using 5\% HCL (v/v), then $2 \mu \mathrm{l}$ of hydrolyzed EPS was spotted onto commercial, aluminum-backed TLC Silica Gel 60 F254 plates (Merck, Germany). Equivalent amounts of fructose, sucrose, and glucose were dissolved in $1 \mathrm{ml}$ of $1 \%$ ethanol and used as standards. The plates were placed in a closed jar with mobile phase chloroform/acetic acid/water at a ratio (7:7:1). After drying, the plates were sprayed with a solution of $\mathrm{H}_{2} \mathrm{SO}_{4} /$ ethanol $(9: 1 \mathrm{v} / \mathrm{v})$ followed by heating for $5-10 \mathrm{~min}$ at $90^{\circ} \mathrm{C}$ to visualize the carbohydrates [27]. Then, the Rfvalues of the ascending materials were calculated [28].

The presence of fructose in the EPS produced by $P$. agglomerans ZMR7 was detected by potassium ferricyanide (PF) sugar test. Briefly, $1 \mathrm{ml} \mathrm{PF}$ solution $(10 \mathrm{mg} / \mathrm{ml}$ in $20 \% \mathrm{NaOH})$ was added to $1 \mathrm{ml}$ acid-hydrolyzed EPS $(1 \mathrm{mg} / \mathrm{ml})$, gently mixed, and the color change was observed. Fructose and glucose served as control [29]. The functional groups of the intact EPS produced by $P$. agglomerans ZMR7 were analyzed using a Shimadzu FT-IR-8300/8700 spectrometer (Shimadzu, Japan) between the 4,000-to- $400 \mathrm{~cm}^{-1}$ region at mid-temperature $\left(26 \pm 1^{\circ} \mathrm{C}\right.$ ), with a resolution of $4.0 \mathrm{~cm}^{-1}[25] .{ }^{1} \mathrm{H}$ and ${ }^{13} \mathrm{C}$ nuclear magnetic resonance (NMR) spectra were measured and recorded using an Avance III $400 \mathrm{MHz}$ spectrometer (Bruker, Germany). Ten milligrams of produced EPS were dissolved in $1 \mathrm{ml}$ of deuterium oxide $\left(\mathrm{D}_{2} \mathrm{O}\right)$. The ${ }^{1} \mathrm{H}$ NMR spectrum was run at $400 \mathrm{MHz}$ while the ${ }^{13} \mathrm{C}$ NMR spectrum was run at $100 \mathrm{MHz}$. The chemical shifts were obtained and presented as ppm. The obtained spectra were compared with those of other levans described in previous publications.

\section{Optimization of Levan Production}

The optimization of cultural parameters was carried out by determining the effect of individual factors and incorporating these at the optimum level before optimizing the next parameter and the quantity of the produced levan was estimated. The effect of sucrose concentration on levan production was assessed at various concentrations $(50,100,200,300,400$, and $500 \mathrm{~g} / \mathrm{l})$. The production media were inoculated with $P$. agglomerans ZMR7 and incubated at $35^{\circ} \mathrm{C}$ for $48 \mathrm{~h}$. Furthermore, six nitrogen sources were used to investigate their impact on levan production. The yeast extract in the original production medium was substituted uniquely with each nitrogen source (casein, peptone, yeast extract, beef extract, ammonium chloride and potassium nitrate). The optimum temperature for levan production was determined by cultivating P. agglomerans ZMR7 at various 
temperatures $\left(25,30,35,37\right.$, and $\left.40^{\circ} \mathrm{C}\right)$. To assess the influence of $\mathrm{pH}$ value on the levan production by P. agglomerans ZMR7, the production medium was adjusted at various $\mathrm{pH}$ values $(4.0,5.0,6.0,7.0$ and 8.0). The optimal incubation period for levan production was investigated by the determination of levan yield after different incubation periods $(24,48,72,96$, and $120 \mathrm{~h})$.

Biological Activities of Levan Produced by P. agglomerans ZMR7

Antiproliferation activity. The antiproliferative activity of the produced levan was evaluated, in vitro, against rhabdomyosarcoma (RD) and breast cancer (MDA-MB-231 ATCC HTB-26) cell lines using colorimetric cell viability MTT assay [30]. Briefly, $100 \mu \mathrm{l} /$ well of RD and MDR cells $\left(10^{6} \mathrm{cell} / \mathrm{ml}\right)$ were cultured in RPMI-1640 medium supplemented with FBS $(10 \%)$, penicillin $(100 \mathrm{U} / \mathrm{ml})$ and streptomycin $(100 \mu \mathrm{g} / \mathrm{ml})$ and added to 96 -well tissue culture plates $(50 \mu \mathrm{l} /$ well). Then, $100 \mu \mathrm{l}$ of $P$. agglomerans ZMR7 levan EPS solution was added to each well to final concentrations of $19,39,78,156,312,625,1,250,2,500 \mu \mathrm{g} / \mathrm{ml}$ and incubated at $37^{\circ} \mathrm{C}$ for $24 \mathrm{~h}$. After incubation, $10 \mu \mathrm{l}$ (3-(4,5-dimethylthiazolyl-2)-2,5-diphenyltetrazolium bromide (MTT) solution ( $5 \mathrm{mg} / \mathrm{ml})$ was added to each well and incubated at $37^{\circ} \mathrm{C}$ for $4 \mathrm{~h}$. Finally, $50 \mu \mathrm{l}$ dimethyl sulfoxide (DMSO) was added to each well and incubated for $10 \mathrm{~min}$. RD and MDA cells cultured in the same medium without levan were used as control. The optical density (OD) was measured for each well at $\mathrm{A}_{620} \mathrm{~nm}$ using a microplate reader. The growth inhibition percent was calculated according to the formula:

$$
\text { Growth Inhibition }(\mathrm{GI} \%)=\frac{(\mathrm{OD} \text { of control wells }-\mathrm{OD} \text { of test wells })}{\mathrm{OD} \text { of control wells }} \times 100
$$

Antileishmanial activity. The antileishmanial activity of levan produced by $P$. agglomerans ZMR7 against promastigote forms of Leishmania tropica was estimated by using the colorimetric cell viability MTT assay [31]. Leishmania promastigotes $(100 \mu \mathrm{l} /$ well $)$ were cultured in 96 -well tissue culture plates $\left(10^{6}\right.$ parasite $\left./ \mathrm{ml}\right)$. Then, $100 \mu \mathrm{l}$ of various concentrations of the produced levan EPS was added to each well to final concentrations of 19 , $39,78,156,312,625,1,250,2,500 \mu \mathrm{g} / \mathrm{ml}$ and incubated at $26^{\circ} \mathrm{C}$ for $24 \mathrm{~h}$. After incubation, $10 \mu \mathrm{l}$ of MTT solution $\left(5 \mathrm{mg} / \mathrm{ml}\right.$ ) was added to each well and incubated at $26^{\circ} \mathrm{C}$ for $4 \mathrm{~h}$. Finally, $50 \mu \mathrm{l} \mathrm{DMSO}$ was added to each well and incubated for another $10 \mathrm{~min}$. Promastigotes cultured in the same medium without levan served as a control. The optical density (OD) was measured for each well at $620 \mathrm{~nm}$ using a microplate reader. The growth inhibition percent was calculated as follows:

$$
\text { Growth Inhibition }(\mathrm{GI} \%)=\frac{(\mathrm{OD} \text { of control wells }- \text { OD of test wells })}{\text { OD of control wells }} \times 100
$$

Antioxidant Activity. The antioxidant activity of the levan produced by $P$. agglomerans ZMR7 was determined in vitro using 2,2-diphenyl-1-picrylhydrazyl (DPPH) free radical scavenging assay. Levan solutions of different concentrations $(0.2-2 \mathrm{mg} / \mathrm{ml})$ were prepared in DW. One milliliter of levan EPS solution was intensively mixed well with $2 \mathrm{ml}$ of freshly prepared DPPH radical solution and incubated in dark for $1 \mathrm{~h}$ at room temperature. Subsequently, the DPPH radical scavenging activity was determined by measuring the absorbance at $\mathrm{A}_{517} \mathrm{~nm}$ using the CE1021 UV-Visible Spectrophotometer (Cecil, UK). Levan solution in ethanol was used as a blank while a mixture of ethanol and DPPH was used as control. The DPPH scavenging inhibition \% activity was calculated according to the following formula:

Scavenging activity $\%=\{(\mathrm{B}-\mathrm{S}) / \mathrm{B}\} \times 100$,

whereas, B (absorbance of blank), S (absorbance of the sample).

\section{Statistical Analysis}

The statistical analysis was conducted by IBM SPSS Statistics software 22 for Windows (IBM, USA) and GraphPad Prism version 7 (GraphPad Software, Inc., USA). All data were expressed as mean \pm SD and statistical analysis was performed by one-way analysis of variance (ANOVA) of Duncan's test and $p<0.05$ was recognized as significant.

\section{Results}

\section{Isolation, Screening and Identification of EPS-Producing Bacteria}

A total of 128 bacterial colonies of different shapes were isolated from rhizospheres of maize plants. Of these isolates, 16 strains exhibited mucoid and slimy colonies on sucrose-rich media, which could be an indication for levan production. ESP-producing candidates were picked and further examined by quantitative estimation of the produced EPS. Based on the result of quantitative screening for EPS production, the most promising strain, designated ZMR7 and exhibiting the maximum production of the EPS $(9.35 \mathrm{~g} / \mathrm{l})$, was selected for further investigations. Based on $16 \mathrm{~S}$ rRNA gene sequence analysis, the most efficient strain was identified as P. agglomerans ZMR7 (Fig. 1). The nucleotide sequence for the strain was deposited at GenBank (Accession No. MW092882).

\section{Characterization of EPS}

To determine the monosaccharide composition, the EPS produced by P. agglomerans ZMR7 was exposed to acid hydrolysis process followed by TLC. Results revealed that the EPS produced by P. agglomerans ZMR7 is composed of fructose only. The Rf value of fructose standard was identical or so close to that of the acidhydrolyzed EPS. The Rf value of the EPS produced by P. agglomerans ZMR7 was 0.44, which was closer to that of 




Fig. 1. Neighbor-joining phylogenetic dendrogram based on $16 \mathrm{~S}$ rDNA sequences shows the relationship between P. agglomerans ZMR7 and the related taxa.

fructose (0.43). The addition of the PF solution to hydrolyzed EPS, glucose, and fructose, produced a greenishyellow color solution. The color disappeared within $2 \mathrm{~min}$ in the case of the hydrolyzed EPS and fructose whereas the color disappeared after about $5 \mathrm{~min}$ in the case of glucose. These findings suggest that the polysaccharide isolated from P. agglomerans ZMR7 would consist of repeating units of fructose.

The chemical structure of the EPS produced by P. aggloremans ZMR7 was investigated by Fourier transform infrared spectroscopy (FTIR) spectroscopy (Fig. 2). The broad stretching peak of $\mathrm{O}-\mathrm{H}$ stretching is present at $3,417 \mathrm{~cm}^{-1}$. The existence of $\mathrm{C}-\mathrm{H}$ stretching vibration has been observed at around $2,935 \mathrm{~cm}^{-1}$. The three peaks appeared at $1,130,1,083$, and $1,045 \mathrm{~cm}^{-1}$ corresponding to the ring vibration overlapped with the stretching vibration of $\mathrm{C}-\mathrm{OH}$ groups and the glycosidic linkage $\mathrm{C}-\mathrm{O}-\mathrm{C}$ stretching vibration. The FTIR spectroscopy data indicated that the biopolymer produced by $P$. aggloremans ZMR7 was levan type, as summarized in Table 1 .

The ${ }^{1} \mathrm{H}-\mathrm{NMR}$ spectrum of $P$. agglomerans ZMR7 EPS revealed characteristic signals of levan. All of the proton signals were observed between 3.43 and $4.59 \mathrm{ppm}$ in the ${ }^{1} \mathrm{H}-\mathrm{NMR}$ spectrum. Noticeably, no peaks were observed in the anomeric region (5.3 to $4.6 \mathrm{ppm}$ ) (Fig. 3A), reflecting the absence of anomeric protons. Furthermore, the structure of the EPS produced by P. agglomerans ZMR7 was confirmed using ${ }^{13} \mathrm{C}-\mathrm{NMR}$ spectroscopy analysis. The ${ }^{13} \mathrm{C}$ NMR spectrum showed six intense resonances at $60.58,104.38,75.83,76.74,80.35$ and 63.15 that were

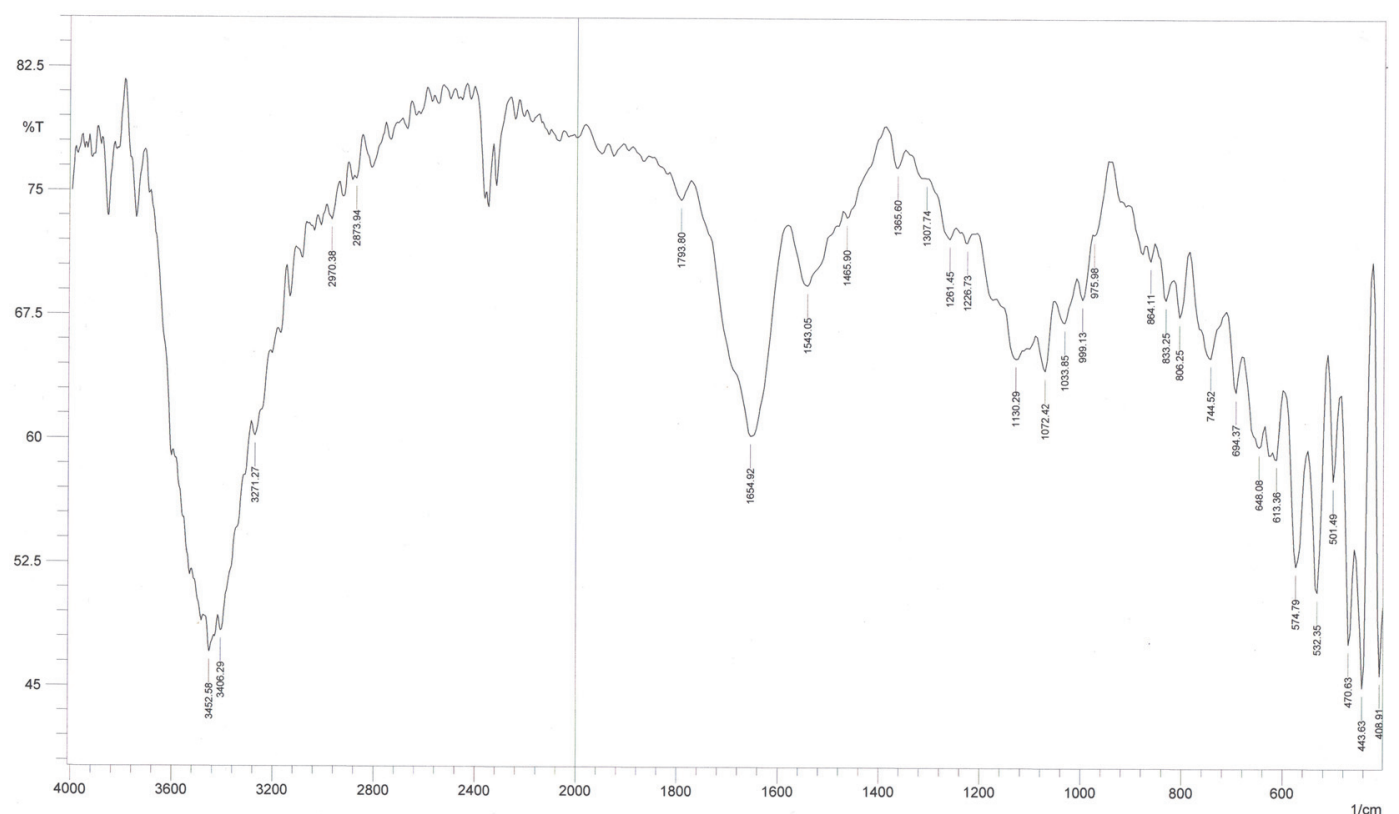

Fig. 2. The FTIR spectrum of the levan produced by rhizospheric P. agglomerans ZMR7. 
Table 1. Comparison between FTIR values of levan produced by P. agglomerans, standard, and other bacteria.

\begin{tabular}{cccccc}
\hline Chemical groups & $\begin{array}{c}\text { Standard levan } \\
\text { from Z. mobilis } \\
\left(\mathrm{cm}^{-1}\right)\end{array}$ & $\begin{array}{c}\text { B. phenoliresistens } \\
\text { Levan } \\
\left(\mathrm{cm}^{-1}\right)\end{array}$ & $\begin{array}{c}\text { P. bovis sp. } \\
\text { Levan } \\
\left(\mathrm{cm}^{-1}\right)\end{array}$ & $\begin{array}{c}\text { B. megaterium } \\
\text { Levan } \\
\left(\mathrm{cm}^{-1}\right)\end{array}$ & $\begin{array}{c}\text { P. agglomerans } \\
\text { Levan } \\
\left(\mathrm{cm}^{-1}\right)\end{array}$ \\
\hline O-H & 3319.26 & 3394.1 & 3423 & 3354.37 & 3417.68 \\
C-H & 2935.48 & 2932.23 & 2935 & 2934.52 & 2935.66 \\
C=O & 1722.31 & 1647.88 & 1636 & 1647.93 & 1639.49 \\
\hline References & {$[25]$} & {$[4]$} & {$[32]$} & {$[33]$} & This study \\
\hline
\end{tabular}

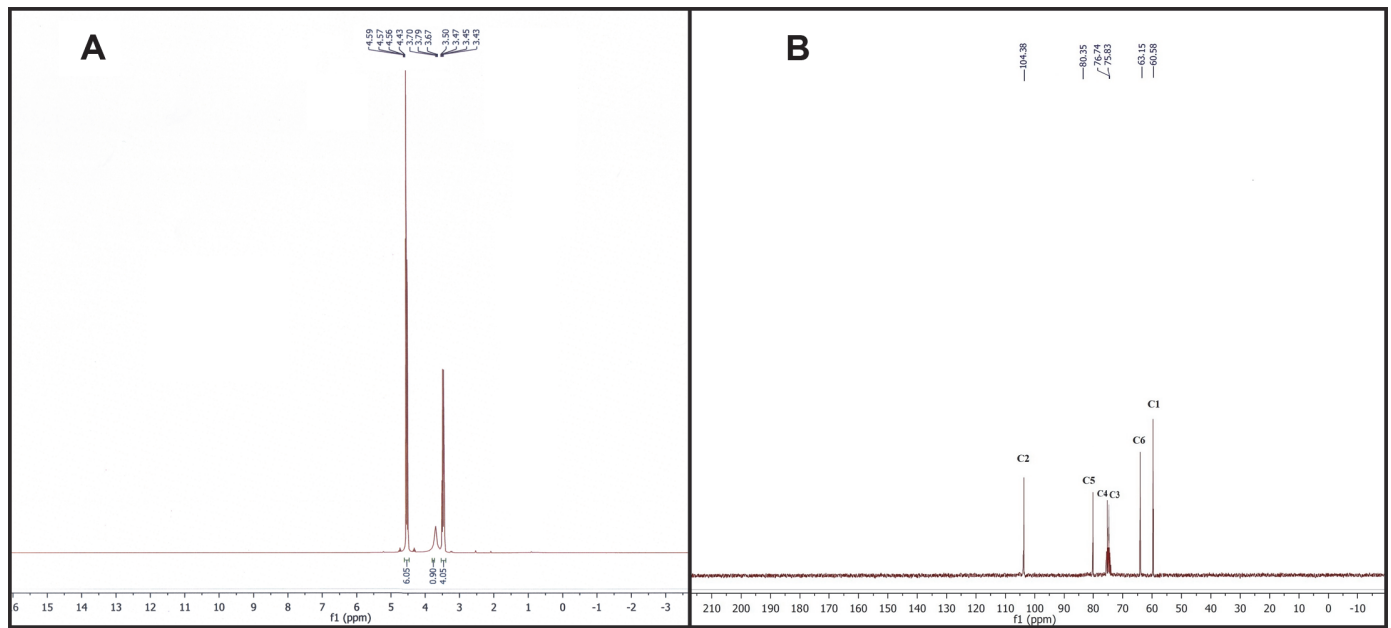

Fig. 3. The ${ }^{1} \mathrm{H}-\mathrm{NMR}(\mathrm{A})$ and ${ }^{13} \mathrm{C}-\mathrm{NMR}$ spectra of the levan produced by $P$. agglomerans ZMR7.

Table 2. ${ }^{13} \mathrm{C}-\mathrm{NMR}$ chemical shift signal values of levan produced by $P$. agglomerans ZMR7 and other bacteria.

\begin{tabular}{ccccc}
\hline \multirow{2}{*}{ Carbon atom } & \multicolumn{4}{c}{ C-NMR chemical shift (ppm) } \\
\cline { 2 - 5 } & $\begin{array}{c}\text { Standard levan } \\
\text { from Z. mobilis }\end{array}$ & $\begin{array}{c}\text { B. megaterium } \\
\text { GJT321 }\end{array}$ & $\begin{array}{c}\text { B. methylotrophicus } \\
\text { SK 21.002 }\end{array}$ & $\begin{array}{c}\text { P. agglomerans } \\
\text { ZMR7 }\end{array}$ \\
\hline C-1 & 60.761 & 59.86 & 61.20 & 60.58 \\
C-2 & 104.641 & 104.14 & 104.66 & 104.38 \\
C-3 & 77.683 & 76.25 & 77.51 & 75.83 \\
C-4 & 75.754 & 75.15 & 76.10 & 76.74 \\
C-5 & 80.783 & 80.23 & 80.77 & 80.35 \\
C-6 & 63.957 & 63.31 & 63.94 & 63.15 \\
\hline Reference & {$[25]$} & {$[33]$} & {$[23]$} & This study \\
\hline
\end{tabular}

assigned to the $\mathrm{C} 1$ to $\mathrm{C} 6$ atoms of the levan structure, respectively (Fig. 3B) (Table 2). It was noteworthy that the downfield signal shift at $63.15 \mathrm{ppm}(\mathrm{C}-6)$ revealed the $\beta-(2 \rightarrow 6)$ linkage. To the best of our knowledge, ours is the first report to describe and characterize the levan-type EPS from Pantoea species.

\section{Optimization of Levan Production}

Unequivocally, results revealed the stimulating impact of increased sucrose concentration on levan production by $P$. agglomerans ZMR7 (Fig. 4A). The amount of produced levan was gradually increased by increasing the concentration of sucrose and the maximum amount of levan $(15.23 \mathrm{~g} / \mathrm{l})$ was observed at a concentration of $400 \mathrm{~g} / \mathrm{l}$. Further increase in sucrose concentration resulted in a drastic decrease in the yield of levan. The levan yield was dramatically increased $(19.11 \mathrm{~g} / \mathrm{l})$ when ammonium chloride was used as the sole nitrogen source, in comparison with the yield obtained by using yeast extract in the original production medium (Fig. 4B). The lowest yield of levan was observed when the production medium was supplemented with casein as a nitrogen source (7.42 g/l).

To further investigate the optimal conditions of levan production, different incubation temperatures were evaluated. The results clarified that the optimal incubation temperature for levan production by $P$. agglomerans ZMR7 was $35^{\circ} \mathrm{C}$ at which the highest production level was observed. Notably, levan production is decreased when the temperature is raised over the optimal temperature (Fig. 4C). To precisely assess the effect of initial pH on the yield of levan, the production media were adjusted at various $\mathrm{pH}$ values ranged from 4.0 to 9.0. The amount of levan produced by P. agglomerans ZMR7 increased gradually with increase of the $\mathrm{pH}$ values from 4 to 8 (Fig. 4D). The highest amount of levan $(21.74 \mathrm{~g} / \mathrm{l})$ was produced at a $\mathrm{pH}$ value of 8.0. The optimal incubation period for levan production was also investigated (Fig. 4E). The amount of produced levan progressively increased after $24 \mathrm{~h}$ of incubation time and the maximum levan production $(28.4 \mathrm{~g} / \mathrm{l})$ was achieved after $96 \mathrm{~h}$ of incubation. 
A

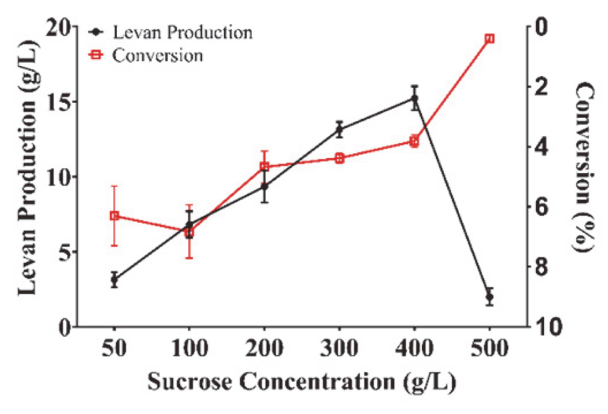

C

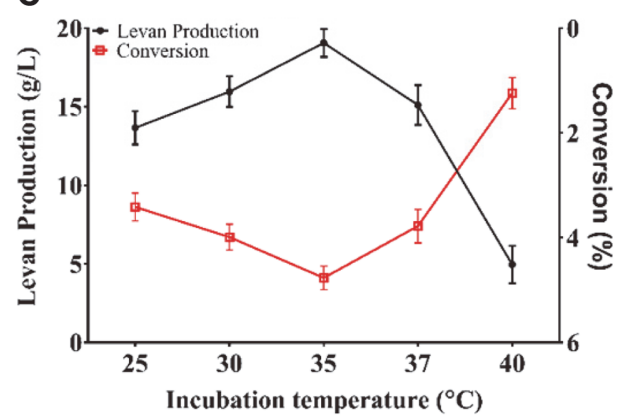

B

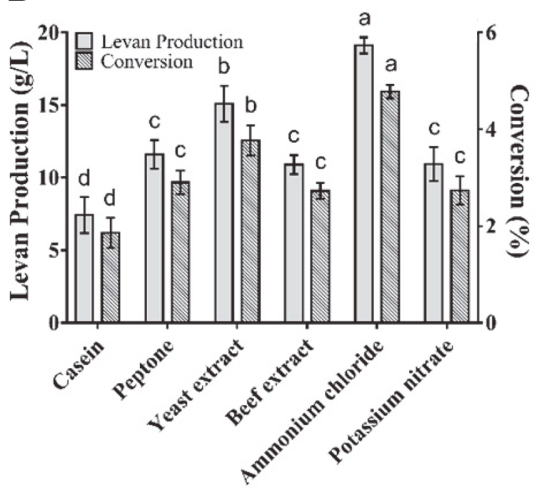

D

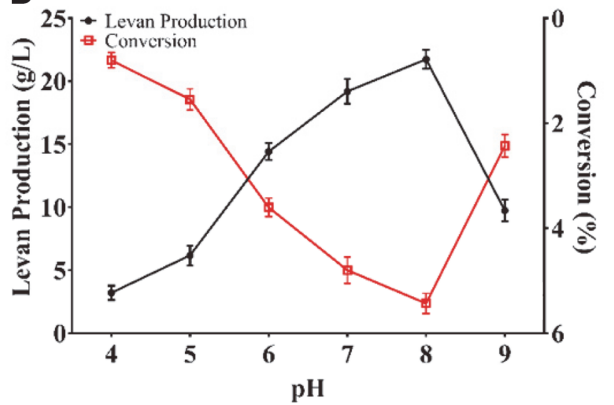

E

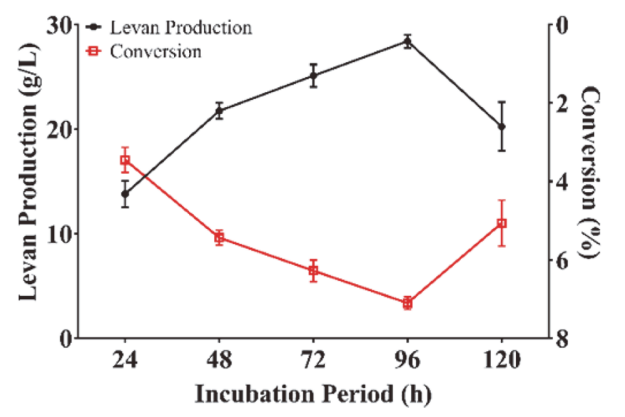

Fig. 4. Impact of sucrose concentration (A), various nitrogen sources (B), incubation temperature (C), initial $\mathrm{pH}(\mathrm{D})$ and incubation period (E) on levan production and conversion of sucrose to levan by P. agglomerans ZMR7. Error bars represent standard deviations (SD). Columns headed by the same letter are not significantly different according to Duncan's multiple range test $(p<0.05)$.

\section{Antiproliferative, Antileishmanial, and Antioxidant Activities of Levan Produced by P. agglomerans ZMR7}

Levan exhibited antiproliferative activities toward both investigated cell lines (Fig. 5A). The results revealed dose-dependent anticancer activities of levan against $\mathrm{RD}$ cells where the cytotoxicity effect increased by increasing the levan concentration. Notwithstanding, the levan produced by P. agglomerans ZMR7 showed different behavior towards MDA cells. The maximum cytotoxicity effect of levan (72.3\%) was exerted at a concentration of $156 \mu \mathrm{g} / \mathrm{mL}$ and the further increase of the concentration did not promote further cytotoxicity. Consequently, the antiproliferative activity of levan could fluctuate towards different cell types. Levan produced by $P$. agglomerans ZMR7 reduced the viability of promastigotes of $L$. tropica at various concentrations (Fig. 5B). The growth of promastigotes of $L$. tropica treated with levan $(2,500 \mu \mathrm{g} / \mathrm{mL})$ was inhibited by about $69.8 \%$, reflecting the potential antileishmanial activities of levan. Although the antileishmanial mechanism of levan is not known, it could be concluded that levan produced from P. agglomerans ZMR7 can be used as a putative antileishmanial agent.

To determine the antioxidant activity of levan produced by P. agglomerans ZMR7, DPPH free radical scavenging assay was used in comparison to ascorbic acid. The ascorbic acid served as a standard antioxidant agent at different concentrations. Ascorbic acid displayed about $80.6 \%$ scavenging activity at a concentration of $200 \mu \mathrm{g} / \mathrm{ml}$, while the levan demonstrated $16.3 \%$ antioxidant activity at the same concentration (Fig. 5C). The highest antioxidant activity of levan was noticed at a concentration of $2 \mathrm{mg} / \mathrm{ml}$, exhibiting $89.3 \%$ scavenging activity. 
A



B

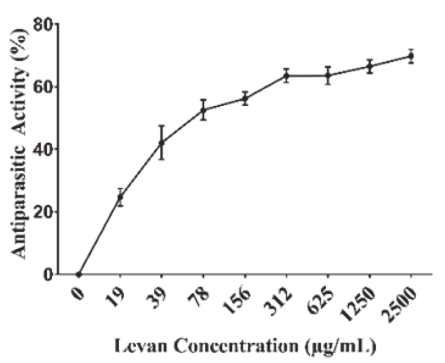

C

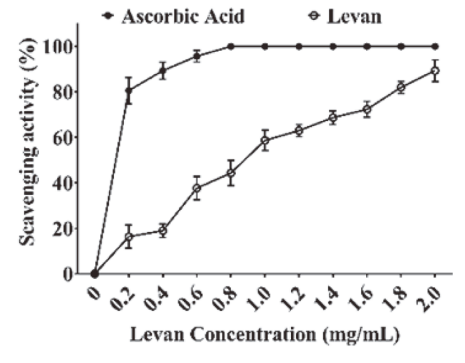

Fig. 5. Biological activity of levan produced by P. agglomerans ZMR7: Antiproliferative effect against MDA and RD cell lines using MTT assay (A), antiparasitic effect against promastigotes of $L$. tropica (B), antioxidant activity (DPPH free radical scavenging ability) of levan produced by $P$. agglomerans ZMR7 and ascorbic acid as a standard $(\mathrm{C})$.

\section{Discussion}

The newly isolated strain P. agglomerans ZMR7 exhibited promising ability to produce EPS from sucrose. In order to elucidate its structure, the purified EPS was subjected to FTIR, ${ }^{1} \mathrm{H}$ NMR and ${ }^{13} \mathrm{C}$-NMR spectroscopy. Also, the monosaccharide composition of the purified EPS was investigated after the acid hydrolysis process. TLC analysis of the acid-hydrolyzed EPS clarified that fructose is the main composition of EPS. These results are similar to those of previous studies reporting the levan production by other bacterial strains [11,27], suggesting the liberation of fructose only as a final hydrolysis product of the EPS. However, the Rf value for the same substance may differ according to various changes like different particle sizes for different batches of the adsorbent, the composition of the mobile phase, the amount of tank atmosphere saturation with mobile phase vapor, and storage conditions of silica gel plate [34]. The FTIR spectrum of the EPS produced by P. aggloremans ZMR7 shed light on its chemical structure. The stretching vibration of the existence of $\mathrm{C}-\mathrm{H}$ and the broad band at $1,639 \mathrm{~cm}^{-1}$ were due to the bound water [32]. The observed three peaks corresponded to ring vibration overlapped with stretching vibration of $\mathrm{C}-\mathrm{OH}$ groups and the glycosidic linkage $\mathrm{C}-\mathrm{O}-\mathrm{C}$ stretching vibration [29]. Besides, due to symmetrical stretching vibration, peaks appeared in the range of $990-806 \mathrm{~cm}^{-1}$, indicating the presence of the furanoid ring and the bending vibration of $\mathrm{D}$-type $\mathrm{C}-\mathrm{H}$ existing in furanose, respectively, which is typical of peaks of carbohydrates [34]. The FTIR spectrum result of the biopolymer produced by P. aggloremans ZMR7 in this study is consistent with FTIR spectra of levan produced by Paenibacillus bovis. nov BD3526 [32], Bacillus megaterium GJT321 [33], and B. phenoliresistens [4]. The levan-type EPS produced by P. agglomerans ZMR7 was also unveiled by ${ }^{1} \mathrm{H}$ NMR spectroscopy, which revealed that the proton signals corresponded to the spectrum of the standard levan of Zymomonas mobilis [35], and Bacillus licheniformis levan [27]. This result was consistent with published data indicating that the ${ }^{1} \mathrm{H}-\mathrm{NMR}$ spectrum of a levan standard exhibits six proton shifts which were between (3.4 and 4.2) ppm [36]. Furthermore, ${ }^{1}$ HNMR data also clarified that the EPS produced by $P$. agglomerans ZMR7 was entirely constituted by fructose units, where peaks are missing in the anomeric region $[37,38] .{ }^{13} \mathrm{C}-\mathrm{NMR}$ spectroscopy analysis has further confirmed the structure of the EPS produced by P. agglomerans ZMR7, and, the signal shifts also matched those of other levans produced by various bacteria such as $Z$. mobilis [25], B. megaterium GJT321 [33], and Bacillus sp. [14] isolated from honey. Additionally, the EPS is confirmed to be levan and not an inulin structure [39], where signals were shifted at $63.15 \mathrm{ppm}$.

Production medium development is an essential strategy to get a higher yield using any microbial strain [40]. Several factors affecting the production of levan were examined, with sucrose among the factors that enhanced the productivity of $P$. agglomerans ZMR7 for levan. The data in this study revealed that the increased concentrations of sucrose will inevitably increase the amount of levan production, whereas a noticeable decrease in the yield of levan was observed under a high concentration of sucrose. Taking this result, the amount of levan is proportional to sucrose concentration [41-43]. The stimulatory effect of sucrose could be because it serves as a substrate for levansucrase [37]. The observed adverse effect of sucrose at $500 \mathrm{~g} / \mathrm{l}$ could be due to the inhibitory osmotic stress. These findings concur with the previous literature on levan [44]. In our study, ammonium chloride as the sole nitrogen source improved levan production in comparison with other investigated sources. Likewise, efficient levan production by Bacillus licheniformis NS032 using ammonium chloride as the sole nitrogen source has been reported [45]. However, several studies reported that the supplementation of organic nitrogen sources to the production medium for polysaccharide production could exert significant stimulating effects on the growth rate and the polysaccharide yield.

Interestingly, maximum levan production was detected at $35^{\circ} \mathrm{C}$ although the optimum temperature for growth of $P$. agglomerans ZMR7 is $30^{\circ} \mathrm{C}$ (data not shown). These findings suggest that levan production could be attributed to the optimum temperature for levansucrase activity rather than direct cell growth. Previously, several reports described the optimum temperature for the levan yield ranging from 25 to $37^{\circ} \mathrm{C}$. Above this range of temperature, the levan yield may be reduced [46]. Several studies referred to the effect of acidity on levan production; here we intended to produce levan under different $\mathrm{pH}$ values. The result of our investigation revealed that $P$. agglomerans ZMR7 tends to produce levan in slightly alkaline conditions. On the other hand, the acidity 
was not shown to be suitable for good levan production and these results were consistent with those reported for levan production by Halomonas smyrnensis $\mathrm{AAD6}^{\mathrm{T}}$, where the highest amount of levan was obtained at a $\mathrm{pH}$ ranged between 7-8 [47]. Regarding the incubation period, P. agglomerans ZMR7 produced the maximum amount of levan after $96 \mathrm{~h}$ of incubation. These results are consistent with previous results reporting the maximum production of levan after $72-120 \mathrm{~h}$ of incubation $[4,20]$. It is worth mentioning that the overall optimization process enhanced the productivity of levan by P. agglomerans ZMR7. At optimum conditions, the strain ZMR7 converted $7.1 \%$ of sucrose to levan and remarkable productivity of the culture was gained (28.4 g/l). The optimized productivity of levan-type EPS attained in this work was higher than those obtained from Bacillus tequilensis GM (2.9 g/l) [48], Bacillus subtilis AF17 (7.9 g/l) [38], Acetobacter xylinum NCIM2526 (13.25 g/l) [29], and Pseudomonas fluorescens $(15.42 \mathrm{~g} / \mathrm{l})$ [25]. Indeed, an efficient levan-producing Pseudomonas mandelii converted $37.8 \%$ of the sucrose in the medium to levan with a yield of $36.7 \mathrm{~g} / \mathrm{l}$ [49]. Recently, it has been reported that Paenibacillus sp. strain FP01 produced levan with high yield $(89.5 \mathrm{~g} / \mathrm{l})$ and was outstanding for its exceptionally high conversion rate of sucrose to levan (49.7\%) [50].

The inhibitory activity of levan EPS produced by P. agglomerans ZMR7 towards RD cell lines is dose dependent. These results agree with previous studies reporting the inhibitory activity of levan against various cancer cell lines such as BGC-823 (human gastric cancer), A549 (human lung adenocarcinoma), HepG2/C3A (human liver hepatocellular carcinoma), AGS (human gastric adenocarcinoma), and MCF-7 (human breast adenocarcinoma) [51]. In contrast, the cytotoxic effect of levan EPS produced by P. agglomerans ZMR7 towards MDA was varied and does not correlate with levan concentrations. Consequently, the antiproliferative activity of levan could fluctuate towards different cell types. Nevertheless, the mode of action of levan against cancer cells is not well understood and it has been suggested that the inhibitory effects of levan towards MCF-7 cells were mediated by an increase in apoptosis and oxidative stress and associated with increased gene expression of p53 and p27 [52]. The antioxidant activity of levan EPS produced by $P$. agglomerans ZMR7 was examined and although it exhibits an antioxidant activity at only a high concentration in comparison to ascorbic acid, this result is in good agreement with previously published reports on the promising antioxidant activity of levan. The robust action of levan as an antioxidant agent may suggest that it is a good candidate antioxidant additive for pharmaceutical products, food processing, and other biomedical uses $[29,53]$.

\section{Conclusion}

A new levan-producing strain of $P$. agglomerans ZMR7 was isolated from rhizospheric soil of $Z$. mays plant. The optimization process enhanced levan yield from 9.35 to $28.4 \mathrm{~g} / \mathrm{l}$. The levan production was stimulated by sucrose and ammonium chloride to produce an adequate amount of the biopolymer under optimum conditions. Moreover, levan produced by P. agglomerans ZMR7 exhibited promising anticancer, antiparasitic, and antioxidant activities, suggesting its potential application in the pharmaceutical field.

\section{Conflict of Interest}

The authors have no financial conflicts of interest to declare.

\section{References}

1. Öner ET, Hernández L, Combie J. 2016. Review of Levan polysaccharide: from a century of past experiences to future prospects. Biotechnol. Adv. 34: 827-844

2. González-Garcinuño Á, Tabernero A, Sánchez-Álvarez JM, Galán MA, Martin del Valle EM. 2017. Effect of bacteria type and sucrose concentration on levan yield and its molecular weight. Microb. Cell Fact. 16: 91.

3. Gamal AA, Hashem AM, El-Safty MM, Soliman RA, Esawy MA. 2020. Evaluation of the antivirus activity of Enterococcus faecalis Esawy levan and its sulfated form. Biocatal Agric. Biotechnol. 28: 101735.

4. Moussa TAA, Al-Qaysi SAS, Thabit ZA, Kadhem SB. 2017. Microbial levan from Brachybacterium phenoliresistens: characterization and enhancement of production. Process Biochem. 57: 9-15.

5. Zhang J, Yue X, Zeng Y, Hua E, Wang M, Sun Y. 2018. Bacillus amyloliquefaciens levan and its silver nanoparticles with antimicrobial properties. Biotechnol. Biotechnol. Equip. 32: 1583-1589.

6. van den Ende W, Coopman M, Clerens S, Vergauwen R, le Roy K, Lammens W, et al. 2011. Unexpected presence of graminan- and levan-type fructans in the evergreen frost-hardy eudicot pachysandra terminalis (buxaceae): purification, cloning, and functional analysis of a 6-SST/6-SFT enzyme. Plant Physiol. 155: 603-614.

7. Liu Q, Yu S, Zhang T, Jiang B, Mu W. 2017. Efficient biosynthesis of levan from sucrose by a novel levansucrase from Brenneria goodwinii. Carbohydr. Polym. 157: 1732-1740.

8. Srikanth R, Reddy CHSSS, Siddartha G, Ramaiah MJ, Uppuluri KB. 2015. Review on production, characterization and applications of microbial levan. Carbohydr. Polym. 120: 102-114.

9. Desai M, Patel K. 2019. Isolation, optimization, and purification of extracellular levansucrase from nonpathogenic Klebsiella strain L1 isolated from waste sugarcane bagasse. Biocatal. Agric. Biotechnol. 19: 101107.

10. Balkrishna A, Agarwal V, Kumar G, Gupta AK. 2018 Applications of Bacterial Polysaccharides with Special Reference to the Cosmetic Industry. pp. 189-2002. In Singh J, Sharma D, Kumar G, Sharma N (eds.), Microbial Bioprospecting for Sustainable Development. Springer, Singapore.

11. Belghith KS, Dahech I, Belghith H, Mejdoub H. 2012. Microbial production of levansucrase for synthesis of fructooligosaccharides and levan. Int. J. Biol. Macromol. 50: 451-458.

12. Al-Halbosiy MMF, Thabit ZA, Al-Qaysi SA-DAS, Moussa TAA. 2018. Biological activity of levan produced from rhizospheric soil bacterium Brachybacterium phenoliresistens KX139300. Baghdad. Sci. J. 15.

13. Kojić JRS, Vrvić MM, Gojgić-Cvijović G, Beškoski VP, Jakovljević DM. 2016. Microbial polysaccharides: between oil wells, food and drugs. Food Eng. Ser. 313-327.

14. Ragab TIM, Shalaby ASG, Awdan SAE, El-Bassyouni GT, Salama BM, Helmy WA, Esawy MA. 2020. Role of levan extracted from bacterial honey isolates in curing peptic ulcer: in vivo. Int. J. Biol. Macromol. 142: 564-573. 
15. Shih IL, Yu YT, Shieh CJ, Hsieh CY. 2005. Selective production and characterization of levan by Bacillus subtilis (Natto) Takahashi. J. Agric. Food Chem. 53: 8211-8215.

16. Jakob F, Pfaff A, Novoa-Carballal R, Rübsam H, Becker T, Vogel RF. 2013. Structural analysis of fructans produced by acetic acid bacteria reveals a relation to hydrocolloid function. Carbohydr. Polym. 92: 1234-1242.

17. Singh RS, Kaur N. 2010. Microbial biopolymers for edible film and coating applications. Adv. Ind. Biotechnol. 187-216.

18. Gomes TD, Caridade SG, Sousa MP, Azevedo S, Kandur MY, Öner ET, et al. 2018. Adhesive free-standing multilayer films containing sulfated levan for biomedical applications. Acta Biomater. 69: 183-195.

19. Ates O. 2015. Systems Biology of Microbial exopolysaccharides production. Front. Bioeng. Biotechnol. 3: 200.

20. Nasir A, Sattar F, Ashfaq I, Lindemann SR, Chen MH, Van den Ende W, et al. 2020. Production and characterization of a high molecular weight levan and fructooligosaccharides from a rhizospheric isolate of Bacillus aryabhattai. LWT 123: 109093.

21. Chhipa H, Kaushik N. 2017. Fungal and bacterial diversity isolated from Aquilaria malaccensis tree and soil, induces agarospirol formation within 3 months after artificial infection. Front. Microbiol. 8: 1286.

22. Poli A, Kazak H, Gürleyendağ B, Tommonaro G, Pieretti G, Öner ET, et al. 2009. High level synthesis of levan by a novel Halomonas species growing on defined media. Carbohydr. Polym. 78: 651-657.

23. Zhang T, Li R, Qian H, Mu W, Miao M, Jiang B. 2014. Biosynthesis of levan by levansucrase from Bacillus methylotrophicus SK 21.002. Carbohydr. Polym. 101: 975-981.

24. Miller GL. 1959. Use of Dinitrosalicylic acid reagent for determination of reducing sugar. Anal. Chem. 31: 426-428.

25. Jathore NR, Bule MV, Tilay AV, Annapure US. 2012. Microbial levan from Pseudomonas fluorescens: characterization and medium optimization for enhanced production. Food Sci. Biotechnol. 21: 1045-1053.

26. Semjonovs P, Shakirova L, Treimane R, Shvirksts K, Auzina L, Cleenwerck I, et al. 2016. Production of extracellular fructans by Gluconobacter nephelii P1464. Lett. Appl. Microbiol. 62: 145-152.

27. Dahech I, Belghith KS, Belghith H, Mejdoub H. 2012. Partial purification of a Bacillus licheniformis levansucrase producing levan with antitumor activity. Int. J. Biol. Macromol. 51:329-335.

28. Xavier JR, Ramana KV. 2017. Optimization of levan production by cold-active Bacillus licheniformis ANT 179 and fructooligosaccharide synthesis by its levansucrase. Appl. Biochem. Biotechnol. 181: 986-1006.

29. Srikanth R, Siddartha G, Sundhar Reddy CHSS, Harish BS, Janaki Ramaiah M, Uppuluri KB. 2015. Antioxidant and antiinflammatory levan produced from Acetobacter xylinum NCIM2526 and its statistical optimization. Carbohydr. Polym. 123: 8-16.

30. Inglese J. 2010. A practical guide to assay development and high-throughput screening in drug discovery. edited by Taosheng Chen. ChemMedChem. 5: 1398-1399.

31. Mahmoudvand H, Tavakoli R, Sharififar F, Minaie K, Ezatpour B, Jahanbakhsh S, et al. 2015. Leishmanicidal and cytotoxic activities of Nigella sativa and its active principle, thymoquinone. Pharm. Biol. 53: 1052-1057.

32. Xu X, Gao C, Liu Z, Wu J, Han J, Yan M, Wu Z. 2016. Characterization of the levan produced by Paenibacillus bovis sp. nov BD3526 and its immunological activity. Carbohydr. Polym. 144: 178-186.

33. Yu X, Li L, Zhang J, Shen Z, Zhu C, Wang P, et al. 2016. Structural analysis of macromolecular levan produced by Bacillus megaterium GJT321 based on enzymatic method. Int. J. Biol. Macromol. 93: 1080-1089.

34. Ahuja M, Singh S, Kumar A. 2013. International journal of biological macromolecules evaluation of carboxymethyl gellan gum as a mucoadhesive polymer. Int. J. Biol. Macromol. 53: 114-121.

35. Han YW, Clarke MA. 1990. Production and characterization of microbial levan. J. Agric. Food Chem. 38: 393-396.

36. Feng J, Gu Y, Han L, Bi K, Quan Y, Yang C, et al. 2015. Construction of a Bacillus amyloliquefaciens strain for high purity levan production. FEMS Microbiol. Lett. 362: fnv079.

37. Aramsangtienchai P, Kongmon T, Pechroj S, Srisook K. 2020. Enhanced production and immunomodulatory activity of levan from the acetic acid bacterium, Tanticharoenia sakaeratensis. Int. J. Biol. Macromol. 163: 574-581.

38. Bouallegue A, Casillo A, Chaari F, La Gatta A, Lanzetta R, Corsaro MM, et al. 2020. Levan from a new isolated Bacillus subtilis AF17: purification, structural analysis and antioxidant activities. Int. J. Biol. Macromol. 144: 316-324.

39. Taylan O, Yilmaz MT, Dertli E. 2019. Partial characterization of a levan type exopolysaccharide (EPS) produced by Leuconostoc mesenteroides showing immunostimulatory and antioxidant activities. Int. J. Biol. Macromol. 136: 436-444.

40. Farahat MG. 2020. Enhancement of $\beta$-cyclodextrin production and fabrication of edible antimicrobial films incorporated with clove essential Oil/ $\beta$-cyclodextrin inclusion complex. Microbiol. Biotechnol. Lett. 48: 12-23.

41. Dos Santos LF, Bazani Cabral De Melo FC, Martins Paiva WJ, Borsato D, Corradi Custódio Da Silva MDL, Colabone Celligoi MAP 2013. Characterization and optimization of levan production by Bacillus subtilis NATTO. Rom. Biotechnol. Lett. 18: 8413-8422.

42. Silbir S, Dagbagli S, Yegin S, Baysal T, Goksungur Y. 2014. Levan production by Zymomonas mobilis in batch and continuous fermentation systems. Carbohydr. Polym. 99: 454-461.

43. Senthilkumar V, Gunasekaran P. 2005. Influence of fermentation conditions on levan production by Zymomonas mobilis CT2. Indian J. Biotechnol. 4: 491-496.

44. Küçükaşik F, Kazak H, Güney D, Finore I, Poli A, Yenigün O, et al. 2011. Molasses as fermentation substrate for levan production by Halomonas sp. Appl. Microbiol. Biotechnol. 89: 1729-1740.

45. Kekez BD, Gojgic-Cvijovic GD, Jakovljevic DM, Stefanovic Kojic JR, Markovic MD, Beskoski VP, et al. 2015. High levan production by Bacillus licheniformis NS032 using ammonium chloride as the sole nitrogen source. Appl Biochem Biotechnol. 175: 3068-3083.

46. Gonçalves BCM, Mantovan J, Ribeiro MLL, Borsato D, Celligoi MAPC. 2013. Optimization production of thermo active levansucrase from Bacillus subtilis Natto CCT 7712 J. Appl. Biol. Biotechnol. 1: 1-8.

47. Kazak Sarilmiser H, Ates O, Ozdemir G, Arga KY, Toksoy Oner E. 2015. Effective stimulating factors for microbial levan production by Halomonas smyrnensis AAD6T. J. Biosci. Bioeng. 119: 455-463.

48. Abid Y, Azabou S, Casillo A, Gharsallah H, Jemil N, Lanzetta R, et al. 2019. Isolation and structural characterization of levan produced by probiotic Bacillus tequilensis-GM from Tunisian fermented goat milk. Int. J. Biol. Macromol. 133: 786-794.

49. Koșarsoy Ağçeli G, Cihangir N. 2020. Nano-sized biopolymer levan: its antimicrobial, anti-biofilm and anti-cancer effects. Carbohydr. Res. 494: 108068.

50. Cheng R, Cheng L, Zhao Y, Wang L, Wang S, Zhang J. 2021. Biosynthesis and prebiotic activity of a linear levan from a new Paenibacillus isolate. Appl. Microbiol. Biotechnol. 105: 769-787.

51. Liu J, Luo J, Ye H, Zeng X. 2012. Preparation, antioxidant and antitumor activities in vitro of different derivatives of levan from endophytic bacterium Paenibacillus polymyxa EJS-3. Food Chem. Toxicol. 50: 767-772.

52. Queiroz EAIF, Fortes ZB, da Cunha MAA, Sarilmiser HK, Barbosa Dekker AM, Öner ET, et al. 2017. Levan promotes antiproliferative and pro-apoptotic effects in MCF-7 breast cancer cells mediated by oxidative stress. Int. J. Biol. Macromol. 102: $565-$ 570.

53. Dahech I, Harrabi B, Hamden K, Feki A, Mejdoub H, Belghith H, et al. 2013. Antioxidant effect of nondigestible levan and its impact on cardiovascular disease and atherosclerosis. Int. J. Biol. Macromol. 58: 281-286. 